\title{
SECONDARY SCHOOL STUDENTS' GREEN CHEMISTRY EXPERIMENT, KNOWLEDGE, ATTITUDE AND PRACTICE: INSTRUMENT DEVELOPMENT AND AN EXPLORATORY STUDY IN MALAYSIA
}

\author{
${ }^{1 *}$ Fatin Nurfakhrana Mohd Akashah ${ }^{2}$ Nur Syahirah Muhamad Nadzri, ${ }^{3}$ Hafsah Taha \\ ${ }^{1,2,3}$ Faculty of Sciences and Mathematics \\ Sultan Idris Education University \\ 35900 Tanjong Malim, Perak, Malaysia \\ *email: fatinnurfakhrana@gmail.com
}

DOI: https://doi.org/10.37134/jpsmm.vol9.1.2.2019

\begin{abstract}
Green chemistry is an educational approach that is guided by Sustainable Development Education which aims to provide students with the knowledge of scientific solutions on how to solve environmental pollution. This study aimed to develop an instrument to gauge students' level of green chemistry experiment, knowledge, attitude and practice and to test the usability of the questionnaire developed to explore students' green chemistry experiment, knowledge, attitude and practice. This quantitative research employed a newly self-constructed Green Chemistry Awareness Questionnaire. The instrument validity and reliability is estimated by two experts and the reliability of the instrument was estimated during the pilot test, yielding Cronbach's alpha value of 0.926. Questionnaires were distributed to 100 chemistry students from five secondary schools in Muallim district. Data was analyzed using descriptive and inferential statistical analysis to address all research questions. The independent t-test showed no statistical significant difference for all constructs by gender and school location.
\end{abstract}

Keywords: green chemistry, sustainable education, sustainable development, experiment, knowledge, attitude, practice

\section{INTRODUCTION}

The development of science and industrial technology is good in terms of changing our lives to make things easier and productive, but uncontrolled technology will impacts environment negatively. Environmental issues involve water, air and soil pollution as a result of industrial operations that produce waste. This pollution is due to the impact of chemical waste that is not properly handled by responsible parties which will endanger human health and threaten natural resources and ecosystems. Environmental problems that occur in this world can be reduced through education, specifically environmental education. Sustainable development education is a reflection of sustainable development that has been implemented to raise the awareness of society as well as professionals in educational institutions on the importance of changing behavior towards the preservation of sustainability (Karpudewan, Ismail, \& Mohamed, 2009). Sustainable development is a development that meets the needs of the present without compromising the ability of future generations to meet their own needs (UNESCO, 2005).

In Malaysia, sustainable development education has been applied in education system which is stated in National Environmental Policy (2002) and Ministry of Education Malaysia, KPM has developed a curriculum for environmental based education as early as the 1990s for both primary and secondary school level. Sustainable development education has been applied in the secondary school education curriculum especially in chemistry subject that is a basic science which acts as a manufacturer in fulfilling human needs. The basic concept of the various fields of science are added and integrated into the Chemical Sciences, thus giving birth to what is called Green Chemistry (Auliah, Muharram, \& Mulyadi, 2018). According to (Anastas \& Warner, 1998), green chemistry can be defined as the utilization of a set of 12 principles that reduces or eliminates the use or generation of hazardous substances in the design, manufacturer and application of chemical products. Green chemistry is a highly effective approach to pollution prevention because it applies innovative scientific solutions to real world environmental problems (EPA, 1990). 
There is no study conducted in Malaysia analyzed respondents' awareness of the 12 principles of green chemistry (Patah, Arshad, Rosli, \& A.Shukor, 2017). Most green chemistry studies in Malaysia only involved university or matriculation students and pre-service teachers and were conducted to gauge the level of environmental understanding, awareness and knowledge and the involvement of secondary school students (Aini, Nurizan \& Fakru'l-Razi, 2007), in service teachers (Othman, Ong \& Lim, 2004; Aini, Fakru'l-Razi, Lau \& Hashim, 2002), pre-service teachers (Esa, 2010) and households (Norhasmah, Aini, Laily, Sharifah Azizah, Nurizan \& Naimah 2004) in sustainable practices. Hence, this study explored on green chemistry sustainable practices of secondary school students to assess their level of awareness in terms of experiment, knowledge, attitude and practice.

\section{MATERIALS AND METHODS}

This study employed an exploratory survey design. Questionnaires were distributed to 100 chemistry students from five secondary schools in Muallim district. There are two parts in this questionnaire. Part A consists of 3 questions regarding the background of respondent includes gender, race and school location. Part B of the questionnaire consists of four green chemistry constructs: 10 items will represent the level of experiment towards green chemistry, 10 items will represent the level knowledge towards green chemistry, 10 items will represent the level of attitude towards green chemistry and 10 items will represents the level of practices towards green chemistry as shown in Table 1.

Table 1 Constructs and number of items in the instrument

\begin{tabular}{lll}
\hline Construct & Items & Number of items \\
\hline Experiments & $1-10$ & 10 \\
Knowledges & $11-20$ & 10 \\
Attitudes & $21-30$ & 10 \\
Practices & $31-40$ & 10 \\
\hline & Total & 40 \\
\hline
\end{tabular}

All items in Part B are using a five-point Likert's scale: strongly disagree, disagree, neutral, agree and strongly agree. Each item was scored $1-5$ with 1 being strongly disagree and 5 the strongly agree. The construct validity of the questionnaire was estimated by two experts and meets the objectives of this study. The reliability of this study was established using a pilot study by collecting data from 30 respondents. The overall reliability of the instruments for 40 items was found to have Cronbach's alpha 0.926. According to the views Mohd Majid (2005) and Hair et al., (2006, 2010), this value is good and acceptable.

\section{RESULTS AND DISCUSSION}

This section is used to answer all the research questions in this study.

Level of experiments, knowledge, attitudes and practices of high school students on green chemistry.

Table 2: Mean of the four green chemistry constructs

\begin{tabular}{ccc}
\hline Construct & Mean & Std. Deviation \\
\hline Experiment & 4.152 & 0.403 \\
Knowledge & 4.014 & 0.434 \\
Attitude & 3.736 & 0.308 \\
Practice & 3.520 & 0.408 \\
\hline
\end{tabular}


Table 3: Mean Range Interpretation

\begin{tabular}{|c|c|}
\hline Range & Level \\
\hline $1.00-2.33$ & Lower \\
\hline $2.34-3.66$ & Medium \\
\hline $3.67-5.00$ & Higher \\
\hline
\end{tabular}

Table 2 shows green chemistry experiment is more dominant compared to other constructs (mean=4.152, $\mathrm{SD}=0.403$ ). Knowledge is in second place with mean value (mean=4.014, $\mathrm{SD}=0.434$ ) followed by attitude (mean=3.736, $\mathrm{SD}=0.308$ ) and practice $(m e a n=3.520, \mathrm{SD}=0.408)$. Mean value interpretation were analyzed according to Table 3 (Mahat et al., 2017). Based on the Table 3, we can conclude that the level of green chemistry experiment, knowledge and attitude is at high level while the green chemistry practice is at medium level. In Malaysia, the application of green chemistry is only focused on hands-on activities such as experiment because it is easy to implement in laboratory-based pedagogy (Abdull Patah, Arshad, Rosli, \& A.Shukor, 2017). Green chemistry experiment is at the highest level because students can easily understand and applied it during practical learning in laboratories.

Difference in experiments, knowledge, attitudes and practices of high school students on green chemistry for male and female students.

Table 4: Green chemistry levels by gender

\begin{tabular}{|c|c|c|c|c|c|c|}
\hline \multirow[t]{2}{*}{ Construct } & \multicolumn{2}{|r|}{$\begin{array}{c}\text { Male } \\
(\mathrm{n}=50)\end{array}$} & \multicolumn{2}{|r|}{$\begin{array}{c}\text { Female } \\
(\mathrm{n}=50)\end{array}$} & \multirow[t]{2}{*}{$\mathbf{t}$} & \multirow[t]{2}{*}{ Sig. } \\
\hline & Mean & Std. Deviation & Mean & Std. Deviation & & \\
\hline Experiment & 81.72 & 8.192 & 84.36 & 7.769 & -1.653 & 0.101 \\
\hline Knowledge & 79.84 & 8.120 & 80.76 & 9.292 & -0.527 & 0.599 \\
\hline Attitude & 75.44 & 6.155 & 73.96 & 6.134 & 1.204 & 0.231 \\
\hline Practice & 70.24 & 6.924 & 68.04 & 7.923 & 1.478 & 0.142 \\
\hline
\end{tabular}

Significant value $\mathrm{p}<0.05$

Data was analyzed using independent sample t-test at $95 \%$ confidence level. Comparison of independent sample t-test results for gender is shown in Table 4 . Table 4 indicated no statistically significant difference for all constructs between male and female $(\mathrm{p}=0.101,0.599,0.231,0.142$ respectively). Hence, there is no significant difference between gender of high school students for green chemistry experiment, knowledge, attitude and practice. This result also seem to support a study done by (Ahmat, 2016), which found no significant difference in green chemistry knowledge, attitude, value and awareness between gender.

Differences in experiments, knowledge, attitudes and practices of high school students on green chemistry for urban and rural students

Table 5: Green chemistry levels by school location

\begin{tabular}{lllllll}
\hline \multirow{2}{*}{ Construct } & \multicolumn{3}{c}{$\begin{array}{c}\text { Urban } \\
(\mathrm{n}=50)\end{array}$} & \multicolumn{3}{c}{$\begin{array}{c}\text { Rural } \\
(\mathrm{n}=50)\end{array}$} \\
\cline { 2 - 5 } & Mean & Std. Deviation & Mean & Std. Deviation & & Sig. \\
\hline Experiment & 83.04 & 7.900 & 83.04 & 8.283 & 0.000 & 1.000 \\
Knowledge & 81.00 & 8.204 & 79.60 & 9.187 & 0.804 & 0.424 \\
Attitude & 75.72 & 6.221 & 73.68 & 5.984 & 1.671 & 0.098 \\
Practice & 69.28 & 7.448 & 69.00 & 7.594 & 0.186 & 0.853 \\
\hline
\end{tabular}

Significant value $\mathrm{p}<0.05$

Data were analyzed using independent sample t-test at $95 \%$ confidence level. Table 5 indicates no statistically significant difference for all constructs between urban and rural schools $(p=1.000,0.424,0.098$, 
0.853 respectively). Hence, we can conclude that there is no significant difference between schools location of high school students in green chemistry experiment, knowledge, attitude and practice. This result however contradict from a study done by (Ahmat, 2016) which revealed significant difference in green chemistry attitude between schools location.

\section{CONCLUSION}

The findings of this study raise our hope that courses such as green chemistry, when integrated in science methods course, can bring about shifts in value orientations that emphasize environmental protection. In our situation, the experiment construct scored high level compared to other three constructs: knowledge, attitude and practice level of green chemistry. Green chemistry will improve students' understanding through experience student with their daily life. A common purpose of science education and environmental education is to educate students to be responsible citizens and stewards of this earth. Therefore, we hope with this finding will help and give a support to teachers in Malaysia to implement green chemistry curriculum as one of the teaching and learning approach to improve students' understanding.

\section{ACKNOWLEDGEMENTS}

The authors would like to express their gratitude to Dr. Hafsah Taha, lecturer from Chemistry Department for the support.

\section{REFERENCES}

Aini, M.S., Fakhru'l-Razi, A., Lau, S. M. \& Hashim, A.H. (2002). Practices, attitudes and motives for domestic waste recycling. International Journal of Sustainable Development and World Ecology, 9(3), 232-238.

Aini, M.S., Nurizan, Y. \& Fakhru'l-Razi, A. (2007). Environmental comprehension and participation of Malaysian secondary school student. Environmental Educational Research, 13(1), 17-31.

Aman, A.H.L., Harun, A., \& Hussein, Z. (2012). The Influence of Environmental Knowledge and Concern on Green Purchase Intention the Role of Attitude as a Mediating Variable. British Journal of Arts and Social Sciences, 7 (2), 145-167.

Anastas, P.T \& Warner, J.C. (1998). Green Chemistry: Theory and Practice. Oxford: Oxford University Press.

Auliah, A., Muharram \& Mulyadi. (2018). Indonesian Teachers' Perceptions on Green Chemistry Principles: A Case Study of a Chemical Analyst Vocational School. 2nd International Conference on Statistics, Mathematics, Teaching, and Research 2017, ICSMTR 2017, 1028(1).

Devasara, B. (2000). Knowledge of the greenhouse effect among four students. Master's thesis, University Malaya, Kuala Lumpur.

Esa, N. (2010). Environmental knowledge, attitude and practices of student teachers. International Research in Geographical and Environmental Education, 19(1), 39-50.

Hair, J.F., Black, W.C., Babin, B.J., Anderson, R.E. \& Tatham, R.L. (2006). Multivariate Data Analysis. Vol. 6, Pearson Prentice Hall, Upper Saddle River.

Karpudewan, M., Ismail, Z., \& Roth, W.M. (2012). The Efficacy of a Green Chemistry Laboratory-Based Pedagogy: Changes in Environmental Values of Malaysia Pre-Service Teachers. International Journal of Science and Mathematics Education, 10(3), 497-529.

Karpudewan, M., Ismail, Z. H., \& Mohamed, N. (2009). The integration of green chemistry experiments with sustainable development concepts in pre-service teachers' curriculum: Experiences from Malaysia. International Journal of Sustainability in Higher Education, 10(2), 118-135.

Levine, D. S., \& Strube, M. J. (2012). Environmental Attitudes, Knowledge, Intentions and Behaviors among College Students. The Journal of Social Psychology, 152 (3), 308-326.

Mageswary, K., Zurida, I. \& Norita, M. (2006). Ensuring environmental sustainability through teaching and learning chemistry. Paper presented at The 2006 ASAIHL Conference on Education for Sustainable Development (EfSD), Penang Malaysia. 
Mageswary, K., Zurida, I. \& Norita, M. (2006b). Knowledge, beliefs, desires and behavior of chemistry pre-service teachers towards the environment. Paper presented at the International Organization of Science and Technology Education Symposium 2006-Science and Technology Education in the Service of Humankind, Penang, Malaysia.

Mahat, H., Hashim, M., Saleh, Y., Nayan, N., \& Norkhaidi, S. B. (2017). Knowledge and Green Chemistry Practice in Primary School Students. Jurnal Pendidikan Malaysia, 42(1), 41-49.

Mohd Majid Konting. (2005). Kaedah penyelidikan pendidikan. Kuala Lumpur: Dewan Bahasa \& Pustaka.

Noor, N.A.M., Muhammad, A., Kassim, A., Jamil, C.Z.M., Mat, N., Mat, N., \& Salleh, H.S. (2012). Creating green consumers: how environmental knowledge and environmental attitude lead to green purchase behavior? International Journal of Arts \& Sciences, 5 (1), 55-71

Norhasmah, S., Aini, M. S., Laily, P., Sharifah Azizah, H., Nurizan, Y. \& Naimah, S. (2004). Environmental attitude and practices. Malaysian Journal of Consumer and Family Economics, 7, 54-65.

Othman, M.N., Ong, F.S. \& Lim, M.H. (2004). Environmental attitudes and knowledge of teenage consumers. Malaysian Journal of Consumer and Family Economics, 7, 66-78.

Patah, K.A., Arshad, M.Y., Rosli, M.S., \& A.Shukor, N. (2017). Implementation of Sustainable Development Education Through Green Chemistry Informally - Challenges and Opportunities.

UNESCO (2005). Guidelines and recommendations for reorienting teacher education to address sustainability, Education for sustainable development in action, technical paper 2, UNESCO Education Sector, Paris. 